\title{
PENGEMBANGAN BUKU ELEKTRONIK FISIKA DASAR I BERBASIS PENDEKATAN SAINTIFIK PADA MATERI VEKTOR DAN KINEMATIKA
}

\author{
Lois Kusumawati Setiawan ${ }^{1}$, Haerul Pathoni ${ }^{2}$, Alrizal ${ }^{3 *}$ \\ ${ }^{1}$ (Pendidikan Fisika Universitas Jambi) \\ * Corresponding Author. E-mail: ${ }^{1}$ loiskusumawatisetiawan@ gmail.com
}

Receive: $18 / 02 / 2021$

Accepted: 28/03/2021

Published: 19/04/2021

\begin{abstract}
Abstrak
Tujuan dari penelitian ini adalah untuk mengetahui keefektivan buku ajar elektronik fisika dasar 1 berbasis pendekatan saintifik menggunakan aplikasi 3D Pageflip Professional pada materi vektor dan kinematika dan untuk mengetahui persepsi mahasiswa mengenai buku ajar elektronik fisika dasar 1 berbasis pendekatan saintifik menggunakan aplikasi 3D Pageflip Professional pada materi vektor dan kinematika. Desain pengembangan pada penelitian ini menggunakan jenis R\&D (Research and Development) dengan tipe pengembangan model ADDIE. Menurut Rusdi (2018), pelaksanaan langkah-langkah pada setiap tahapan ADDIE dipadu dengan metode penelitian yang sesuai dengan jenis tahapan utama, tujuan dan karakteristik setiap tahap tersebut. Berdasarkan hasil analisis lembar observasi awal terhadap 33 mahasiswa Pendidikan Fisika kelas Reguler C angkatan 2018 yang telah mengontrak mata kuliah fisika dasar 1 , diperoleh data sebesar lebih dari $50 \%$ mahasiswa menyatakan bahwa mata kuliah fisika dasar 1 memiliki tingkat kesulitan pemahaman yang cukup tinggi. Pada materi vektor dan kinematika memiliki persentase kesulitan sebesar 69,7\%. Mahasiswa merasa kesulitan untuk mamahami konsep materi perkuliahan, menjabarkan rumus dan menyelesaikan latihan soal.
\end{abstract}

Kata Kunci: buku elektronik, saintifik, 3d pageflip professional.

\section{Abstract (English-Indonesia)}

The purpose of this study was to determine the effectiveness of the basic physics electronics textbook 1 based on a scientific approach using the 3D Pageflip Professional application on vector and kinematics materials and to determine student perceptions of basic physics electronics textbook 1 based on a scientific approach using the 3D Pageflip Professional application on vector material. and kinematics. The development design in this study uses the R\&D (Research and Development) type with the ADDIE model development type. According to Rusdi (2018), the implementation of the steps at each ADDIE stage is combined with research methods that are in accordance with the types of main stages, objectives and characteristics of each stage. Based on the results of the analysis of the preliminary observation sheets on 33 Physics Education students of Class C Class 2018 who had contracted the basic physics subject 1, it was obtained that more than $50 \%$ of students stated that basic physics 1 had a fairly high level of understanding difficulty. In vector and kinematics material has a difficulty percentage of $69.7 \%$. Students find it difficult to understand the concept of lecture material, describe formulas and complete practice questions.

Keywords: electronic book, scientific, 3d pageflip professional. 
Jurnal Edumaspul, 5 (1), Year 2021 - 615

(Lois Kusumawati Setiawan, Haerul Pathoni, Alrizal)

\section{Pendahuluan}

Pemahaman konsep fisika
merupakan kemampuan dalam
mengetahui, mendefisinisikan dan juga
membahasakan sendiri konsep dari
pembelajaran fisika yang telah dipelajari
tanpa mengurangi maknanya (Hanna, dkk.
2016). Pembelajaran fisika dapat
mengantarkan pemahaman pada konsep
fisika dan keterkaitannya untuk
memecahkan masalah dalam kehidupan
sehari-hari. Oleh karena itu, pemahaman
erat kaitannya dengan mempelajari ilmu
fisika. Pemahaman diekspresikan dalam
bentuk informasi,
memanfaatkan dan mengekstrapolasi
pengetahuan tersebut untuk dimanfaatkan
dalam situasi lain (Novitasari \& Supriadi,
2018).

Menurut Darlen, Sjarkawi \& Lukman (2015), buku merupakan sumber ilmu pengetahuan yang tiada batas dan salah satu sumber belajar yang digunakan dalam pembelajaran. Seiring dengan perkembangan peralatan teknologi pada saaat ini. Pengadaan buku sebagai sumber belajar tidak hanya sebatas buku yang berbentuk cetak tetapi juga sudah ada buku dalam bentuk digital yang sering dikenal sebagai buku elektronik (e-book). Salahh satu manfaat dari buku elektronik adalah tidak membutuhkan penggunaan kertas sehingga buku elektronik dianggap ramah lingkungan.

Buku elektronik adalah versi elektronik dari buku. Buku elekronik lebih mudah dibawa kemana-mana karena ukurannya yang dapat menyesuaikan dengan handphone, tablet, komputer dan lain sebagainya, dibandingkan dengan buku cetak yang pada umumnya dimiliki oleh mahasiswa maupun dosen (Octamela, Suweken Ardana, 2019:306). Terdapat berbagai macam buku elektronik yang dapat digunakan, diantaranya adalah teks polos, pdf, doc., lit dan html. Seiring dengan perkembangan teknologi, buku elektronik sudah dapat disertai dengan musik, video, maupun animasi-animasi yang membuat tampilan dari buku elektronik lebih menarik. Buku elektronik fisika dasar 1 berbasis pendekatan saintifik dibuat dengan menggunakan aplikasi 3D Pageflip Professional.

Menurut 3D Pageflip Professional (2012) dalam Kurniawati (2016), software ini merupakan perangkat lunak yang mengubah file dalam bentuk PDF menjadi halaman 3D animasi dengan menyertakan teks, video, gambar, animasi, video, suara dan lain-lain. Dengan adanya pembaharuan dalam bidang teknologi diharapkan dapat memberikan nuansa baru bagi dosen dan mahasiswa dalam proses pembelajaran. Produk yang dikembangkan dalam penelitian ini berisi materi dan soal-soal vektor dan kinematika,seperti contohcontoh yang berkaitan dengan kehidupan sehari-hari, percobaan sederhana. Sehingga buku elektronik yang dikembangkan dapat membantu mahasiswa memahami materi dengan baik. Keefektivan dalam menggunakan buku elektronik ini dapat diperoleh dari penyebaran lembar observasi awal.

Menurut (Bermawi \& Fauziah, 2016), dalam pembelajaran terdapat istilah makna seperti pendekatan saintifik. Pendekatan saintifik merupakan pendekatan pembelajaran yang memberikan kesempatan kepada setiap peserta didik untuk aktif secara luas mengembangkan eksplorasi dan elaborasi dari materi yang telah dipelajari, kemudian peserta didik diberi kesempatan untuk melakukan tahapan-tahapan dalam mengamati, merumuskan masalah, merumuskan hipotesis, mengumpulkan data, menganalisis data, menarik kesimpulan dan kemudian mengkomunikasikannya. Peserta didik dapat menggali informasi dari mana saja 
dan kapan saja serta tidak hanya bergantung kepada pendidik. Dalam hal ini, diharapkan mempu melatih peserta didik dalam mencari informasi melalui berbagai observasi bukan hanya diberi tahu oleh pendidik.

\section{Metode}

Penelitian ini termasuk jenis penelitian pengembangan dengan menggunakan pendekatan saintifik. Penelitian pengembangan merupakan metode penelitian yang fungsinya untuk mengembangkan (memvalidasi) produkproduk yang digunakan dalam pembelajaran dan pendidikan (Borg and Gall dalam Sugiyono:2009). Produk yang dikembangkan berupa buku elektronik fisika dasar 1 menggunakan aplikasi 3D Pageflip Professional. Desain pengembangan pada penelitian ini menggunakan jenis R\&D (Research and Development) dengan tipe pengembangan model ADDIE. Menurut Rusdi (2018), pelaksanaan langkah-langkah pada setiap tahapan ADDIE dipadu dengan metode penelitian yang sesuai dengan jenis tahapan utama, tujuan dan karakteristik setiap tahap tersebut.

Jenis data pada penelitian ini adalah data kualitatif dan data kuantitatif. Data kuantitatif diperoleh dari komentar dan saran yang diperoleh dari validasi ahli media dan ahli materi, kemudian data kuantitatif diperoleh dari hasil angket persepsi mahasiswa. Subjek uji coba dalam penelitian ini adalah mahasiswa pendidikan fisika kelas reguler c angkatan 2018 di universitas jambi yang telah mengontrak mata kuliah fisika dasar 1. Instrumen pengumpulan data pada penelitian ini berupa lembar validasi ahli materi dan ahli media, angket observasi awal dan angket kebutuhan mahasiswa.

\section{Hasil dan Pembahasan}

Berdasarkan hasil observasi awal melalui pengisian angket kebutuhan terhadap bahan ajar oleh 33 mahasiswa Pendidikan Fisika kelas Reguler C angkatan 2018 yang mengontrak mata kuliah fisika dasar 1 di Universitas Jambi, diperoleh data bahwa $100 \%$ mahasiswa membutuhkan bahan ajar tambahan untuk menunjang pembelajaran pada matakuliah tersebut. Sedangkan berdasarkan analisis terhadap angket kebutuhan, 66,7\% mahasiswa belum pernah menggunakan bahan ajar berbasis saintifik dalam pembelajaran. Berdasarkan angket yang telah di sebar menunjukkan 63,6\% mahasiswa menginginkan bahan ajar yang memuat gambar, dan $78,8 \%$ mahasiswa menginginkan penjabaran rumus yang rinci.

Berdasarkan permasalahan di atas, maka dibutuhkan komponen penunjang proses pembelajaran yang dapat digunakan untuk membantu mahasiswa dalam kegiatan belajar mengajar. Salah satu komponen yang mempengaruhi hal tersebut adalah penggunaan bahan ajar. Bahan ajar fisika dasar 1 yang digunakan di Universitas Jambi masih berupa bahan ajar cetak dan jumlahnya masih sangat terbatas. Berkaitan dengan permasalahan tersebut, penulis memberikan alternatif dengan membuat bahan ajar elektronik yang dilengkapi dengan gambar, penjabaran rumus, latihan soal, dan simulasi atau percobaan. Buku elektronik merupakan salah satu media yang dapat digunakan untuk mengatasi permasalahan dalam proses pembelajaran.

Menurut Prabowo dan Heriyanto (2013:4), buku elektronik merupakan bentuk digital dari sebuah buku yang berisi informasi tertentu. Buku elektronik memiliki format penyajian yang runtut, bahasa yang baik, tinggi kadar keilmuannya dan luas pembahasannya. Buku elektronik yang digunakan dalam penelitian ini berbasis pendekatan saintifik, yang bertujuan agar mahasiswa tidak hanya dapat berfikir kritis dalam menyelesaikan 
persoalan, akan tetapi juga mampu memahami konsep.

Mahasiswa diajak dapat menemukan konsep serta menurunkan rumus pada materi vektor dan kinematika dengan lima langkah pembelajaran pada pendekatan saintifik. Adapun lima langkah pembelajaran saintifik menurut Kemendikbud (2014), yaitu mengamati, menanya, mengumpulkan informasi, mengasosiasi dan mengkomunikasikan. Karena produk yang dikembangkan berupa buku yang prinsipnya sebagai sumber belajar mandiri mahasiswa, maka langkah pembelajaran pendekatan saintifik pada bahan ajar yang dikembangkan ini berfokus pada langkah mengamati dan mengumpulkan informasi. Buku elektronik fisika dasar 1 berbasis pendekatan saintifik dibuat dengan menggunakan aplikasi $3 D$ Pageflip Professional.

Menurut 3D Pageflip Professional (2012) dalam Kurniawati (2016), software ini merupakan perangkat lunak yang mengubah file dalam bentuk PDF menjadi halaman 3D animasi dengan menyertakan teks, video, gambar, animasi, video, suara dan lain-lain. Dengan adanya pembaharuan dalam bidang teknologi diharapkan dapat memberikan nuansa baru bagi dosen dan mahasiswa dalam proses pembelajaran. Produk yang dikembangkan dalam penelitian ini berisi materi dan soal-soal vektor dan kinematika,seperti contohcontoh yang berkaitan dengan kehidupan sehari-hari, percobaan sederhana. Sehingga buku elektronik yang dikembangkan dapat membantu mahasiswa memahami materi dengan baik. Keefektivan dalam menggunakan buku elektronik ini dapat diperoleh dari penyebaran lembar observasi awal.

Berdasarkan hasil analisis lembar observasi awal terhadap 33 mahasiswa Pendidikan Fisika kelas Reguler $\mathrm{C}$ angkatan 2018 yang telah mengontrak mata kuliah fisika dasar 1, diperoleh data sebesar lebih dari 50\% mahasiswa menyatakan bahwa mata kuliah fisika dasar 1 memiliki tingkat kesulitan pemahaman yang cukup tinggi. Pada materi vektor dan kinematika memiliki persentase kesulitan sebesar $69,7 \%$. Mahasiswa merasa kesulitan untuk mamahami konsep materi perkuliahan, menjabarkan rumus dan menyelesaikan latihan soal.

Kebanyakan mahasiswa menyatakan bahwa kesulitan yang dialami dalam pemahaman materi perkuliahan terletak pada keterbatasan bahan ajar yang belum dapat menjelaskan materi perkuliahan secara rinci. Bahan ajar yang selama ini digunakan cukup sulit untuk dipahami dan belum memenuhi kebutuhan dari $84,8 \%$ mahasiswa terhadap bahan ajar. Faktor penyebab sulitnya dalam memahami bahan ajar yaitu bahasa yang digunakan sulit untuk dipahami, rumus tidak dijabarkan secara detail dan tidak terdapat penyelesaian latihan soal.

Hasil Pengisian Lembar Observasi Awal

\begin{tabular}{lll}
\hline Pertanyaan & \multicolumn{2}{l}{ Jawaban } \\
Mahasiswa
\end{tabular}


Jurnal Edumaspul, 5 (1), Year 2021 - 616

(Lois Kusumawati Setiawan, Haerul Pathoni, Alrizal)

\begin{tabular}{|c|c|}
\hline & $\begin{array}{l}\text { (16) } \\
\text { - Fungsi Lagrange } \\
\text { (19) } \\
\text { - Fluida Statis dan } \\
\text { Fluida Dinamis } \\
\text { (8) } \\
\end{array}$ \\
\hline $\begin{array}{l}\text { 3. Kesulitan } \\
\text { seperti apa } \\
\text { yang Anda } \\
\text { temukan } \\
\text { selama } \\
\text { mempelajari } \\
\text { mata kuliah } \\
\text { Fisika Dasar } 1 \text { ? }\end{array}$ & 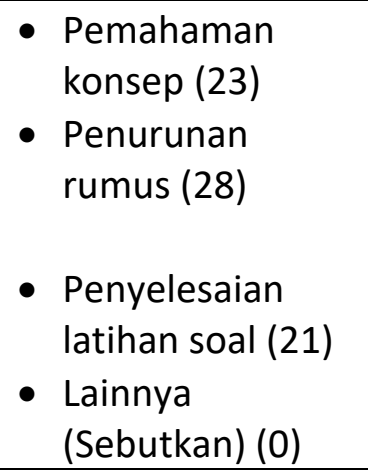 \\
\hline $\begin{array}{l}\text { 4. Apa saja jenis } \\
\text { bahan ajar yang } \\
\text { digunakan oleh } \\
\text { dosen untuk } \\
\text { menjelaskan } \\
\text { materi } \\
\text { perkuliahan? }\end{array}$ & $\begin{array}{l}\text { - LKS (4) } \\
\text { - Modul (25) } \\
\text { - E-book (25) }\end{array}$ \\
\hline $\begin{array}{l}\text { 5. Referensi / } \\
\text { buku apa yang } \\
\text { digunakan } \\
\text { dosen untuk } \\
\text { menjelaskan } \\
\text { materi } \\
\text { perkuliahan? }\end{array}$ & $\begin{array}{l}\text { - Analitical } \\
\text { Mechanics (Grant } \\
\text { R Fowles) (16) } \\
\text { - Seri Fisika dasar } \\
\text { Seri Mekanika } \\
\text { (Sutrisno) (23) } \\
\text { - Mechanics (Keith } \\
\text { R Symon) (12) } \\
\text { - Lainnya } \\
\text { (Sebutkan) (0) }\end{array}$ \\
\hline $\begin{array}{l}\text { 6. Apakah } \\
\text { referensi dan } \\
\text { bahan ajar yang } \\
\text { ada saat ini } \\
\text { sudah } \\
\text { memenuhi } \\
\text { kebutuhan } \\
\text { Anda dalam } \\
\text { memahami } \\
\text { materi } \\
\text { perkuliahan? }\end{array}$ & $\begin{array}{l}\text { - Sudah (5) } \\
\text { - Belum (28) }\end{array}$ \\
\hline
\end{tabular}

7. Apa yang • Bahasa yang sulit menyebabkan dipahami (24)

bahan ajar - Rumus tidak tersebut masih diturunkan secara

\begin{tabular}{|c|c|c|}
\hline & $\begin{array}{l}\text { belum bisa } \\
\text { mempermudah } \\
\text { dan memenuhi } \\
\text { kebutuhan } \\
\text { Anda dalam } \\
\text { memahami } \\
\text { materi } \\
\text { perkuliahan? } \\
\text { Sebutkan! }\end{array}$ & $\begin{array}{l}\text { detail (30) } \\
\text { - Penyelesaian } \\
\text { latihan soal (17) } \\
\text { - Lainnya } \\
\text { (Sebutkan) }\end{array}$ \\
\hline 8. & $\begin{array}{l}\text { Apakah } \\
\text { penggunaan } \\
\text { bahasa pada } \\
\text { bahan ajar } \\
\text { (yang } \\
\text { digunakan } \\
\text { dosen) telah } \\
\text { mempermudah } \\
\text { Anda untuk } \\
\text { memahami } \\
\text { materi pembelajaran } \\
\text { mata kuliah } \\
\text { Fisika Dasar } 1 ?\end{array}$ & $\begin{array}{l}\text { - Ya (18) } \\
\text { - Tidak (15) }\end{array}$ \\
\hline 9. & $\begin{array}{lr}\text { Jika } & \text { ada } \\
\text { pengembangan } \\
\text { bahan } & \text { ajar } \\
\text { untuk } & \text { mata } \\
\text { kuliah } & \text { Fisika } \\
\text { dasar } & 1, \\
\text { briteria } \\
\text { bahan } & \text { ajar } \\
\text { seperti } & \text { apa } \\
\text { yang } & \text { ada } \\
\text { inginkan? } & \end{array}$ & 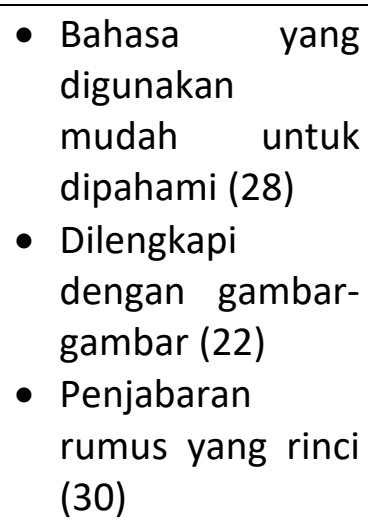 \\
\hline
\end{tabular}

Hasil Pengisian Angket Kebutuhan

Mahasiswa

\begin{tabular}{lll}
\hline Pertanyaan & Hasil \\
\hline 1. & Apakah Anda & $\bullet$ Ya (28) \\
menyukai & $\bullet$ Tidak (3) \\
materi & \\
perkuliahan & \\
mata kuliah & \\
Fisika dasar 1? & \\
\hline 2. & Apakah mata & $\bullet$ Ya (26) \\
kuliah Fisika & $\bullet$ Tidak (5) \\
Dasar $\quad 1$ & \\
merupakan &
\end{tabular}


Jurnal Edumaspul, 5 (1), Year 2021 - 617

(Lois Kusumawati Setiawan, Haerul Pathoni, Alrizal)

\begin{tabular}{|c|c|c|}
\hline & $\begin{array}{lr}\text { mata } & \text { kuliah } \\
\text { dengan } & \text { materi } \\
\text { yang } & \text { sulit } \\
\text { dipahami? } & \\
\end{array}$ & \\
\hline 3. & $\begin{array}{l}\text { Apakah Anda } \\
\text { memiliki bahan } \\
\text { ajar untuk mata } \\
\text { kuliah Fisika } \\
\text { dasar 1? }\end{array}$ & $\begin{array}{l}\text { - Ya (21) } \\
\text { - Tidak (10) }\end{array}$ \\
\hline 4. & $\begin{array}{l}\text { Apakah bahan } \\
\text { ajar yang Anda } \\
\text { gunakan sudah } \\
\text { cukup bagi Anda } \\
\text { untuk } \\
\text { memahami } \\
\text { mata kuliah } \\
\text { tersebut? }\end{array}$ & $\begin{array}{l}\text { - } Y a(4) \\
\text { - Tidak (27) }\end{array}$ \\
\hline 5. & $\begin{array}{l}\text { Apakah Anda } \\
\text { membutuhkan } \\
\text { bahan belajar } \\
\text { tambahan untuk } \\
\text { menunjang } \\
\text { pembelajaran } \\
\text { pada mata } \\
\text { kuliah tersebut? }\end{array}$ & $\begin{array}{l}\text { - Ya (31) } \\
\text { - Tidak (0) }\end{array}$ \\
\hline 6. & $\begin{array}{l}\text { Apakah Anda } \\
\text { pernah } \\
\text { menggunakan } \\
\text { bahan ajar } \\
\text { berbasis } \\
\text { saintifik dalam } \\
\text { mempelajari } \\
\text { pada mata } \\
\text { kuliah Fisika } \\
\text { dasar 1? }\end{array}$ & $\begin{array}{l}\text { - Ya (11) } \\
\text { - Tidak (20) }\end{array}$ \\
\hline 7. & $\begin{array}{l}\text { Jika tidak } \\
\text { pernah, } \\
\text { menurut Anda } \\
\text { apakah bahan } \\
\text { ajar berbasis } \\
\text { saintifik } \\
\text { diperlukan } \\
\text { dalam mata } \\
\text { kuliah fisika } \\
\text { dasar 1? }\end{array}$ & $\begin{array}{l}\text { - Ya (31) } \\
\text { - } \operatorname{Tidak}(0)\end{array}$ \\
\hline 8. & $\begin{array}{l}\text { Konten } \\
\text { tambahan apa }\end{array}$ & - Gambar \\
\hline
\end{tabular}

\begin{tabular}{|c|c|}
\hline $\begin{array}{l}\text { yang Anda } \\
\text { harapkan } \\
\text { terkandung di } \\
\text { dalam bahan } \\
\text { ajar berbasis } \\
\text { saintifik? }\end{array}$ & $\begin{array}{l}\text { - } \text { Penjabaran } \\
\text { rumus yang rinci } \\
\text { (26) } \\
\text { - Video } \\
\text { pembahasan (1) }\end{array}$ \\
\hline 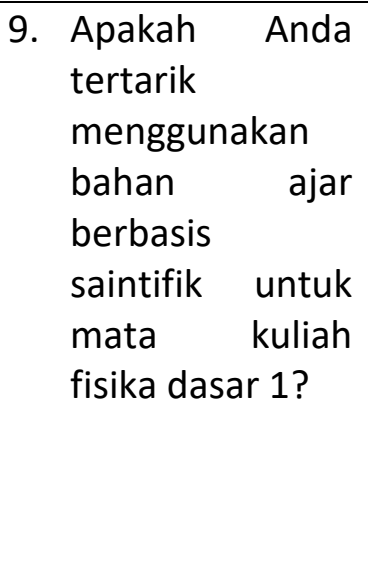 & $\begin{array}{l}\text { - Sangat tidak } \\
\text { tertarik (2) } \\
\text { - Tertarik (20) } \\
\text { - Tidak tertarik (0) }\end{array}$ \\
\hline $\begin{array}{l}\text { 10. Menurut Anda, } \\
\text { apa saja kriteria } \\
\text { materi } \\
\text { pembelajaran } \\
\text { yang } \\
\text { dibutuhkan } \\
\text { dalam bahan } \\
\text { ajar berbasis } \\
\text { saintifik? } \\
\text { Sebutkan! }\end{array}$ & $\begin{array}{l}\text { - } \text { Materi yang sulit } \\
\text { dipahami (28) } \\
\text { - Materi yang } \\
\text { banyak } \\
\text { rumusnya (22) } \\
\text { - Lainnya (0) }\end{array}$ \\
\hline $\begin{array}{lr}\text { 11. Pada } & \text { mata } \\
\text { kuliah } & \text { fisika } \\
\text { dasar } 1 \text { terdapat } \\
\text { salah } r \text { satu } \\
\text { materi } & \text { (Vektor } \\
\text { dan } & \\
\text { Kinematika). } \\
\text { Menurut Anda } \\
\text { apakah materi } \\
\text { tersebut cocok } \\
\text { untuk dibuat } \\
\text { sebagai bahan } \\
\text { ajar berbasis } \\
\text { saintifik? }\end{array}$ & $\begin{array}{l}\text { - Ya (29) } \\
\text { - Tidak (2) }\end{array}$ \\
\hline $\begin{array}{l}\text { 12. Apakah } \\
\text { proses }\end{array}$ & $\begin{array}{l}\text { - Ya (28) } \\
\text { - Tidak (3) }\end{array}$ \\
\hline
\end{tabular}


Jurnal Edumaspul, 5 (1), Year 2021 - 618

(Lois Kusumawati Setiawan, Haerul Pathoni, Alrizal)

\begin{tabular}{l}
\hline menggunakan \\
model, metode, \\
pendekatan \\
ataupun strategi \\
pembelajaran? \\
\hline 13. Menurut Anda, • Ya (28) \\
apakah model, $\bullet$ Tidak (3) \\
metode, \\
pendekatan dan \\
strategi \\
pembelajaran \\
perlu untuk \\
digunakan \\
dalam proses \\
perkuliahan \\
mata kuliah \\
fisika dasar 1 ? \\
\hline 14. Menurut Anda, $\bullet$ Ya (31) \\
apakah \\
pendekatan \\
saintifik sesuai \\
untuk \\
digunakan \\
dalam proses \\
perkuliahan \\
mata kuliah \\
fisika dasar 1 ? \\
\end{tabular}

\section{Simpulan}

Berdasarkan penelitian yang telah dilakukan oleh peneliti, dapat disimpulkan bahwa mahasiswa membutuhkan pengembangan buku ajar elektronik fisika dasar 1 berbasis pendekatan saintifik pada materi vektor dan kinematika yang dilengkapi dengan gambar, video pembelajaran, dan percobaan.

\section{Daftar Pustaka}

Anugraha, R. (2018). Pengantar Mekanika Klasik. Yogyakarta : Gadjah Mada University Press.

Arikunto, S. (2013). Dasar-Dasar Evaluasi Pendidikan Edisi 2. Jakarta: Aksara

$$
\begin{array}{ccc}
\text { Aruan, Mega Sulastri. } & \text { (2019). } \\
\text { Pengembangan Bahan Ajar Berbasis }
\end{array}
$$

Mind Map Menggunakan Aplikasi Mind Master Pada Materi Protozoa Untuk Mahasiswa Pendidikan Biologi Universitas Jambi. Skripsi. Fakultas Matematika dan Ilmu Pengetahuan Alam. Jurusan Biologi. Universitas Jambi

Arsanti, M. (2018). Pengembangan Bahan Ajar Mata Kuliah Penulisan Kreatif Bermuatan Nilai-Nilai Pendidikan Karakter Religius Bagi Mahasiswa Prodi Pbsi, Fkip, Unissula.Jurnal IImiah Bahasa dan Sastra, 1(2).

Bermawi, Y., \& Fauziah, T. (2016). Penerapan Pendekatan Saintifik Dalam Pembelajaran Di Sekolah Dasar Aceh Besar. Jurnal pesona dasar, Vol. 2 No.4, April 2016, hal 63 - 71

Cahyadi, R. A. H. (2019). Pengembangan Bahan Ajar Berbasis Addie Model. Halaqa: Islamic Education Journal, volume 3(1),

Hanna, Daryl., Sutarto., \& Harijanto, Alex. (2016). Model Pembelajaran Tema Konsep Disertai Media Gambar Pada Pembelajaran Fisika di SMA. Jurnal Pendidikan Fisika, Volume 5 Nomor 1.

Iswari, I. (2020). Pengembangan Bahan Ajar Pengukuran Besaran dan Satuan Berorientasi Conceptual Understanding untuk Sekolah Menengah Pertama. Thesis, Universitas Jambi. Diakses dari http://ecampus.fkip.unja.ac.id/eskripsi/?p=det il\&u=cRqIWVCENfCz6W9TPZduH69p03cvMdpl7SIX6ODT8o

Fanani, A., \& Kusmaharti, D. (2006). Pengembangan Pembelajaran Berbasis Hots (Higher Order Thinking Skill) Di Sekolah Dasar Kelas V.Jurnal Pendidikan Dasar,

Hapsari, A. I. (2016). Pengembangan Bahan Ajar Berbasis Video Contextual Untuk Meningkatkan Keterampilan Berpikir Tingkat Tinggi Mahasiswa Pada Mata Kuliah Fisiologi Hewan Development 
Jurnal Edumaspul, 5 (1), Year 2021 - 619

(Lois Kusumawati Setiawan, Haerul Pathoni, Alrizal)

Of Teaching Materials Based On Contextual Video To Improve The Student Higher Order Thingking Skills Of Animal Physiology Course Jurnal Pendidikan Biologi Indonesia, Volume 2 Nomor 1

Kurniawan, D. T., Sanusi, N. M., \& Kharimah, N. I., (2017). Pembelajaran Konsep Mekanika Fluida Statis Berbantuan Praktikum Virtual dalam Mengembangkan Keterampilan Berfikir Kritis Mahasiswa Calon Guru Matematika. Phenomenon, Volume 7 Nomor 2.

Kurniawan, W., Pujaningsih, F.B., Alrizal., Latifah, N. A. (2018). Analisis Kebutuhan Mahasiswa Terhadap Bahan Ajar Sebagai Acuan Pengembangan Modul Fisika Gelombang Bola dan Tabung. Jurnal Edufisika. Vol 3 No 1.

Lambaga, I. A. (2019). Tinjauan Umum Konsep Fisika Dasar.Yogyakarta: Deepublish

Novitasari, F., Supriadi, B., \& Maryani (2018). Identifikasi Miskonsepsi Mahasiswa Program Studi Pendidikan Fisika Angkatan 2018 Universitas Jember Pada Pemahaman Konsep Listrik Statis Dan Dinamis. Jurnal Pembelajaran Fisika, Volume 8 Nomor 4.

Novita, Purba. 2018. "'Pengembangan Modul Elektronik Menggunakan Aplikasi 3D Pageflip Professional Berbasis Saintifik Pada Materi Mekanika Benda Tegar Mata Kuliah Fisika Dasar 1. Skripsi. FKIP, Pendidikan Fisika, Universitas Jambi, Jambi

Pratiwi, W., \& Alimudin, Johan. (2018). Pengembangan Bahan Ajar Bermuatan High Order Thinking Skill (HOTS) pada Pembelajaran Tema Persatuan dalam Perbedaan.Prosiding Seminar Nasional Unimus, Volume 1.

Ramadani, T. L. (2019). Pengembangan Buku Ajar IPA Kelas VIII Semester 1
Berbasis Kearifan Lokal Jambi Menggunakan Pendekatan Saintifik. Thesis, Universitas Jambi. Diakses dari http://e-

campus.fkip.unja.ac.id/eskripsi/?p=det il\&u=cLtSqPYdtql8GKIQgHy18erZZvITiq pqB73YbsHdwBA

Restiarni, E. F. (2017). Pengembangan Modul Elektronik Berbasis High Order Thinking Skills (HOTS) Pada Materi Persamaan Schrodinger Mata Kuliah Fisika Kuantum. Thesis, Universitas Jambi. Diakses dari http://ecampus.fkip.unja.ac.id/eskripsi/?p=det il\&u=6xP2x2zdBAFs1h5zCPj7gcpKAJBrP Eosw2rikggil4

Rusdi, M. (2018). Penelitian Desain dan Pengembangan Kependidikan. Depok: PT RajaGrafindo Persada

Sabaryati, J., \& Isnaini, M. (2018). Pengembangan Media Pembelajaran Mekanika Berbasis Komputerisasi Untuk Membentuk Karakter IImiah Mahasiswa. Jurnal Hasil Kajian, Inovasi, dan Aplikasi Pendidikan Fisika, Vol 4. No 2

Sari, Dewi Ayu Puspita. 2018. "Pengembangan Modul Elektronik Fisika Berbasis Pendekatan Saintifik Pada Materi Getaran Harmonis SMA/MA Menggunakan Kvishop Flipbook Maker". Skripsi. FKIP, Pendidikan Fisika, Universitas Jambi, Jambi.

Sari, W., Jufrida., \& Pathoni , H. (2017). Pengembangan Modul Elektronik Berbasis 3D Pageflip Professional Pada Materi Konsep Dasar Fisika Inti dan Struktur Inti Mata Kuliah Fisika Atom dan Inti. Jurnal EduFisika, Vol. 02 No. 01

Sofyan, F. A. (2019). Implementasi Hots Pada Kurikulum 2013. INVENTA, 3(1), 1-9.

https://doi.org/10.36456/inventa.3.1.a 1803 
Jurnal Edumaspul, 5 (1), Year 2021 - 620 (Lois Kusumawati Setiawan, Haerul Pathoni, Alrizal)

Sugiyono. (2009). Metode Pendidikan.

Bandung : Alfabeta

Taufik, M. (2017). Pengembangan Bahan Ajar Cetak Berbasis Penilaian Kinerja Sebagai Sumber Belajar Bagi Siswa Sd Kelas VI. SCHOOL EDUCATION JOURNAL PGSD FIP UNIMED, 7(3),
285-295.

https://doi.org/10.24114/sejpgsd.v7i3. 9251

Widoyoko, I. (2018). Teknik-Teknik Penyusunan Instrumen Penelitian. Yogyakarta: Pustaka Pelajar 